(2) Open Access Full Text Article

\title{
Cystic lymphatic malformation of the falciform ligament: a rare cause of abdominal mass
}

\author{
This article was published in the following Dove Press journal: \\ Open Access Surgery \\ 2I September 20II \\ Number of times this article has been viewed
}

\author{
Tariq O Abbas' \\ Adel Ismail' \\ Emran Amir ${ }^{2}$ \\ 'Paediatric Surgery Department; \\ 2Pathology Department, Hamad \\ General Hospital, Doha, Qatar
}

Correspondence: Tariq $\bigcirc$ Abbas Paediatric Surgery Department, Hamad General Hospital, Doha, 3050, Qatar

Tel +9745509365I

Email tariq2c@hotmail.com
Introduction: Lymphatic malformations are benign proliferations of the lymphatic vessels that occur most frequently in the skin of the axilla and neck. However, they can also occur in the mediastinum and retroperitoneum, and very rarely in the abdominal cavity.

Case report: An 11-year-old male who presented with an intra-abdominal cyst is described here. Laparoscopic exploration showed that it was a cystic mass of the falciform ligament and it was resected laparoscopically. Histopathology confirmed the swelling to be a lymphatic malformation. To the authors' knowledge, this is only the second report of a pediatric patient with a lymphatic malformation in the falciform ligament.

Conclusion: Intra-abdominal cystic lymphatic malformations should be considered in the differential diagnosis of any intra-abdominal cystic mass. Management is surgical excision.

Keywords: lymphatic malformations, intra-abdominal, falciform ligament

\section{Introduction}

Lymphatic malformations are benign over growths of the lymphatic tissues. Although they usually occur in the skin of the neck and axilla, they can also occur in the mediastinum and retroperitoneum. Lymphatic malformations can be classified according to the radiological appearance of lymphatic cavities. These categories include single cystic, macrocystic (diameter $>1 \mathrm{~cm}$ and cysts $<5 \mathrm{~cm}$ ), microcystic (diameter $<1 \mathrm{~cm}$ and/or cysts $>5 \mathrm{~cm}$ ), and cavernous (multiple cysts [no limit to the size or number] with solid elements containing microscopic channels) $)^{1,2}$ lymphatic malformations.

Lymphatic malformations of the falciform ligament of the liver are extremely rare. To the authors' knowledge, the case described here is only the second to be reported in the literature.

\section{Case report}

An 11-year-old male with no significant medical history presented with abdominal discomfort and increasing upper abdominal distension. There was no fever or weight loss. Physical examination showed an obvious bulge on the right side of his upper abdomen. A cystic spherical mass $5 \times 4 \mathrm{~cm}$ could be palpated in this area. The mass could be moved transversely but had limited vertical or diagonal mobility. His white blood cell count was $8700 / \mathrm{mm}^{3}$, hemoglobin concentration was $9.9 \mathrm{~g} / \mathrm{dL}$, platelet count was $388,000 / \mathrm{mm}^{3}$, and his coagulation profile was normal.

Ultrasonography (Figure 1) and computed tomography scan (Figure 2) of the abdomen showed a multiloculated, well-defined lesion $6.4 \times 6.7 \times 6.8 \mathrm{~cm}$ in the right 


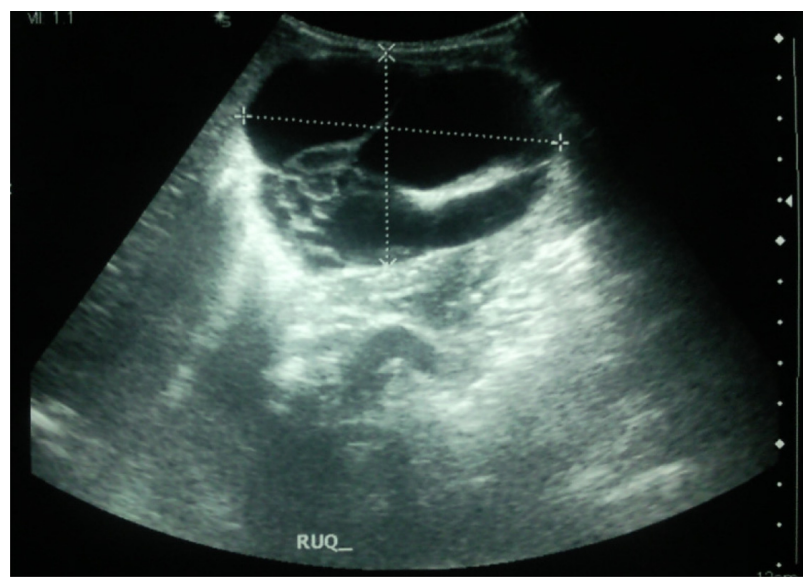

Figure I Abdominal ultrasonography of the patient, showing a multiloculated, welldefined lesion, about $6.4 \times 6.7 \times 6.8 \mathrm{~cm}$ in size, in the right upper abdomen inferior to the liver and gallbladder.

upper quadrant of his abdomen, inferior to the liver and gallbladder and anterior to the pancreas. Some of the locules contained low-level internal echoes. There was no abnormal vascularity within or around the lesion.

Exploratory laparoscopy showed a cystic mass with an approximate diameter of $6 \mathrm{~cm}$ within the falciform ligament (Figure 3). The mass was aspirated and completely resected laparoscopically. Histopathological examination of the specimen showed that it was a lymphatic malformation (Figure 4). The postoperative course of the patient was unremarkable, and he was discharged the following day. He remains well 12 months after surgery.

\section{Discussion}

Lymphatic malformations usually present as cysts, either unilocular or multilocular. Although ultrasonography

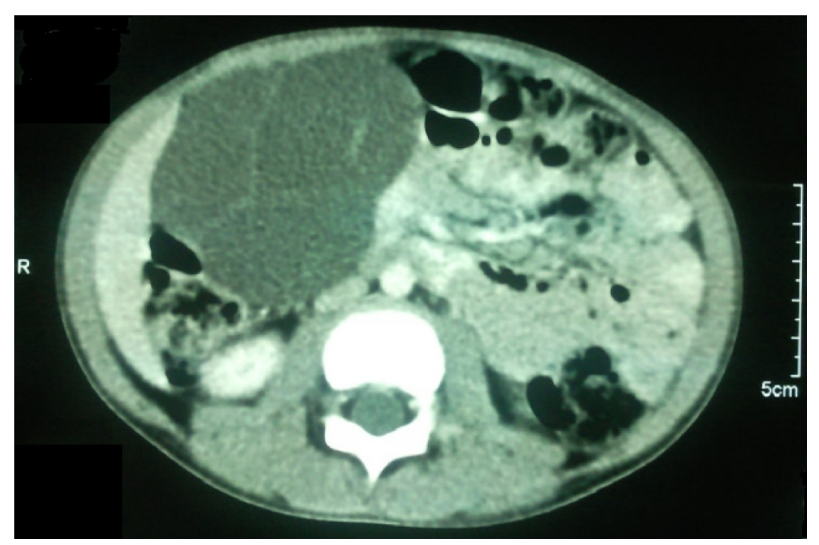

Figure 2 Computed tomography of the abdomen of the patient, showing a multiloculated, well-defined lesion, $6.4 \times 6.7 \times 6.8 \mathrm{~cm}$ in size, inferior to the liver and gallbladder and anterior to the pancreas. Some of the locules contained low-level internal echoes. The mass can be seen to push the bowel to the left side. There was no abnormal vascularity within or around the lesion.

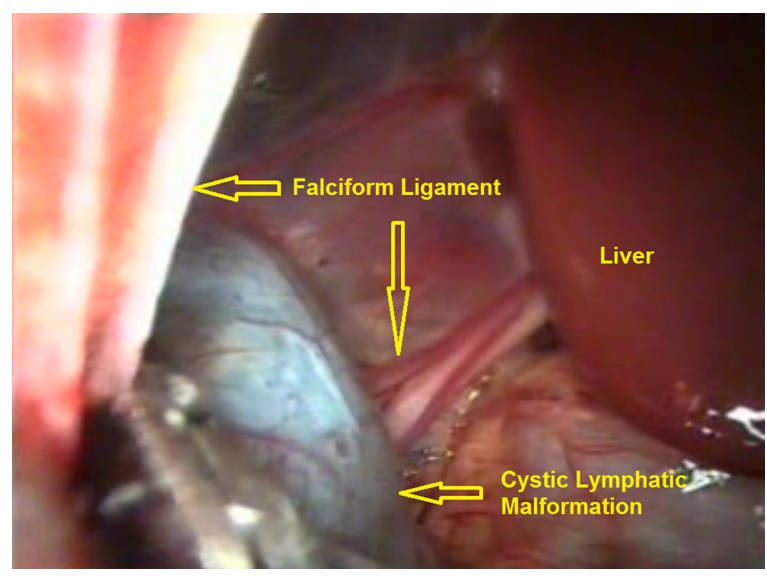

Figure 3 Exploratory laparoscopy, showing a cystic mass with an approximate diameter of $6 \mathrm{~cm}$ within the falciform ligament, surrounded by a thin reflected peritoneal membrane.

and computed tomography scanning can determine the morphology of the lesion, these methods alone are insufficient to determine the site of origin. The differential diagnosis of intra-abdominal lesions includes lesions of congenital origin, such as mesenteric, omental, and choledochal cysts, and, in females, cysts of ovarian origin. Other possibilities include secondary cysts, such as hydatid cysts and abdominal abscesses.

Although the etiology of lymphatic malformations is not known, these lesions may be due to sequestration of segments of primordial endothelial sacs, which give rise to the mature lymphatic system.

Although some lymphatic malformations may be asymptomatic, they may become infected and gradually increase in size, at which time they may cause recurrent abdominal symptoms, as with the patient discussed here.

As the diagnosis is not always certain, the proper management is surgical exploration. Laparoscopy is of great benefit as it can be used to properly explore all quadrants of the abdominal cavity, as well as to completely excise the lesion with minimal trauma, as in the case described.

Lesions of the liver ligaments are extremely rare, with few cysts of the falciform ligament previously reported. ${ }^{3-5}$ Other lesions reported in the falciform ligament and ligamentum teres of the liver include lipomas, ${ }^{6-8}$ paragangliomas, ${ }^{9}$ and leiomyosarcomas. ${ }^{10-15}$ The authors' patient is the second reported in the literature with lymphatic malformation. ${ }^{16}$

The most common symptom of intra-abdominal lymphatic malformations in children is nonspecific abdominal pain. Other frequent symptoms include palpable mass, vomiting, abdominal distension, nausea, and constipation. ${ }^{17}$ Although these lesions grow as the child grows, they are capable 

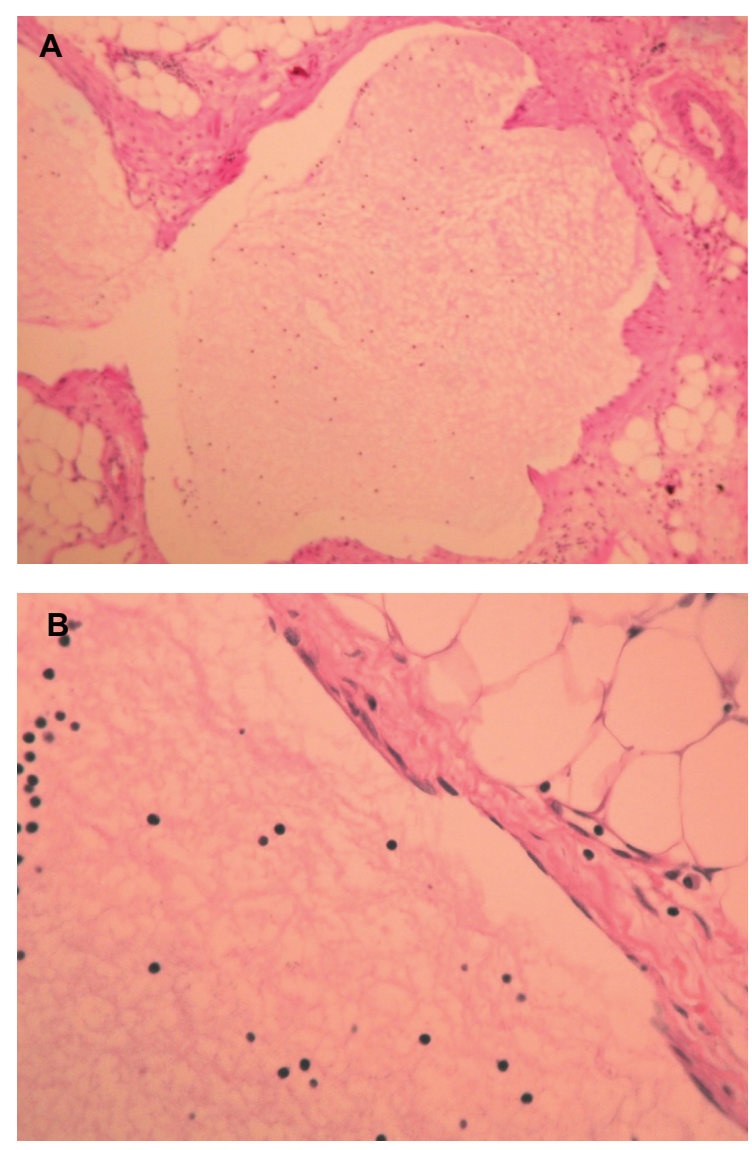

Figure 4 (A) Low power showing dilated lymphatic channels; some of the channels are cystically dilated. (B) Numerous lymphocytes are evident in the lymph with flattened endothelial lining.

of massive expansion and have a tendency to infiltrate surrounding tissues. ${ }^{1}$ Although lymphatic malformations are histologically benign, their expansion into surrounding organs may cause life-threatening complications. ${ }^{18-20}$

\section{Conclusion}

Lymphatic malformation of the falciform ligament is an extremely rare condition that can present in pediatric patients. Although preoperative diagnosis is uncertain, lymphatic malformation should be considered in the differential diagnosis of children with intra-abdominal cysts. Laparoscopic exploration is of benefit in diagnosis as well as in complete surgical excision.

Open Access Surgery

\section{Publish your work in this journal}

Open Access Surgery is an international, peer-reviewed, open access journal that focuses on all aspects of surgical procedures and interventions. Patient care around the peri-operative period and patient outcomes post surgery are key topics. All grades of surgery from minor cosmetic interventions to major surgical procedures are covered. Novel techniques

\section{Disclosure}

The authors report no conflicts of interest in this work.

\section{References}

1. Hancock BJ, St-Vil D, Luks FI, Di Lorenzo M, Blanchard H. Complications of lymphangiomas in children. J Pediatr Surg. 1992;27:220-224; discussion 224-226.

2. Ogita S, Tsuno T, Deguchi E, Tokiwa K, Nagashima M, Iwai N. OK-432 therapy for unresectable lymphangioma in children. $J$ Pediatr Surg. 1991;26:263-268; discussion 268-270.

3. Bryan DH, Pillarisetty S. Cyst of the falciform ligament of the liver: a rare cause of right upper quadrant pain. Am Surg. 1992;58:779-781.

4. Brock JS, Pachter HL, Schreiber J, Hofstetter SR. Surgical diseases of the falciform ligament. Am J Gastroenterol. 1992;87:757-758.

5. Enterline DS, Rauch RE, Silverman PM, Korobkin M, Akwari OE Cyst of the falciform ligament of the liver. AJR Am J Roentgenol. 1984; $142: 327-328$.

6. Farkas E, Besznyak I, Koves I. Giant lipoma of the ligamentum teres hepatic. Orv Hetil. 1991;132:637-638. Hungarian.

7. Kakitsubata Y, Nakamura R, Shiba T, et al. Lipoma of the falciform ligament: US, CT, and MRI appearances. Clin Imaging. 1993;17: 27-29.

8. Honda H, Watanabe K, Mihara K, Hoshi H, Sakihama M. Ipoma of the hepatic falciform ligament. J Comput Assist Tomogr. 1983;7:170.

9. Delbridge L, Connolly J. Paraganglioma of the falciform ligament: a case report. Aust N ZJ Surg. 1982;52:315-317.

10. Okajima K, Kobayashi M, Mannami T, et al. Primary leiomyosarcoma of the peritoneum - report of a rare case rising in the falciforme ligament of the liver. Gan No Rinsho. 968;14:500-507.

11. Morita Y, Saito H, Okushiba S, Shinohara M, Satoh N, Uchino J. A case report of leiomyosarcoma of the hepatic falciform ligament - clinical significance of the hepatic alciform artery. Rinsho Hoshasen. 1987; 32:1613-1616. Japanese.

12. Yamaguchi J, Azuma T, Fujioka H, et al. Leiomyosarcoma occurring in the ligamentum teres of the liver: a case report and a review of seven reported cases. Hepatogastroenterology. 1996;43:1051-1056.

13. Tomaszewski MM, Kuenster JT, Hartman K. Leiomyosarcoma of ligamentum teres of liver: case report. Pediatr Pathol. 1986;5: $147-156$.

14. Adachi M, Sugita T, Maehara M, et al. A case report of leiomyosarcoma originating in the ligamentum teres of the liver. Gastroenterol Jpn 1979;14:238-242.

15. Mital RN, Bazaz-Malik G. Leiomyosarcoma of ligamentum teres of the liver. Am J Gastroenterol. 1971;56:48-51.

16. Morgan K, Ricketts RR. Lymphangioma of the falciform ligament a case report. J Pediatr Surg. 2004;39:1276-1279.

17. Kosir MA, Sonnino RE, Gauderer MW. Pediatric abdominal lymphangiomas: a plea for early recognition. J Pediatr Surg. 1991;26: 1309-1313.

18. Ravitch MM, Rush BF Jr. Cystic hygroma. In: Welch KJ, Randolph JG, Ravitch MM, O'Neill JA, Rowe MI, editors. Pediatric Surgery. 4th ed. Chicago, IL: Year Book Medical; 1986:533-539.

19. Emery PJ, Bailey CM, Evans JN. Cystic hygroma of the head and neck. A review of 37 cases. J Laryngol Otol. 1984;98:613-619.

20. Trán-Ngoc-Ninh, Trán-Xuân-Ninh. Cystic hygroma in children: a report of 126 cases. J Pediatr Surg. 1974;9:191-195.

\section{Dovepress}

and the utilization of new instruments and materials, including implants and prostheses that optimize outcomes constitute major areas of interest. The manuscript management system is completely online and includes a very quick and fair peer-review system. Visit http://www.dovepress.com/ testimonials.php to read real quotes from published authors. 